\title{
Impact of operation condition on temperature distribution in single cell of polymer electrolyte fuel cell operated at higher temperature than usual
}

\author{
Akira NISHIMURA*, Masato YOSHIMURA*, Amira Hakimi MAHADI*, Masafumi HIROTA* and \\ Mohan Lal KOLHE** \\ *Division of Mechanical Engineering, Graduate School of Engineering, Mie University \\ 1577 Kurimamachiya-cho, Tsu, Mie 514-8507, Japan \\ E-mail: nisimura@mach.mie-u.ac.jp \\ **Faculty of Engineering and Science, University of Agder \\ PO Box 422, NO 4604, Kristiansand, Norway
}

Received 10 May 2016

\begin{abstract}
For improving performance of the stationary Polymer Electrolyte Fuel Cell (PEFC) system, the cell operating temperature up to $90{ }^{\circ} \mathrm{C}$ will be preferred in Japan during the period from 2020 to 2030. To understand the operation of the PEFC system under relatively high temperature conditions, detail heat and mass transfer analysis is required. The main focus of this study is to analyze the PEFC performance under operational conditions, such as initial operational temperature of cell $\left(T_{\text {ini }}\right)$, relative humidity of supply gas, and the cathode gas type, temperature distribution in a cell of PEFC (using Nafion membrane) under relatively higher operating temperature conditions. The in-plane temperature distributions on backside of gas separator of cell under power generation were measured using thermograph and it was observed that the in-plane temperature distribution at the anode was more uniform than that at the cathode under the $\mathrm{O}_{2}$ supply condition, irrespective of $T_{\text {ini, }}$, relative humidity of supply gases except $T_{\text {ini }}$ of $100{ }^{\circ} \mathrm{C}$. As to $T_{\text {ini }}$ of $100{ }^{\circ} \mathrm{C}$, the in-plane temperature distribution at the anode was broader since the back diffusion of water from the cathode to the anode was helped compared to the other $T_{\text {ini. }}$. The temperature at the cathode was raised through the gas channel toward the outlet of cell for the relative humidity of supply gases of $100 \% \mathrm{RH}$ at $T_{\text {ini }}$ of $90{ }^{\circ} \mathrm{C}$, while the temperature increase was relatively smaller at $T_{\text {ini }}$ of $80{ }^{\circ} \mathrm{C}$. The in-plane temperature distribution at the anode under the air supply condition was broader compared to not only that at the cathode, but also that at the anode under the $\mathrm{O}_{2}$ supply condition. It is necessary to manage the water concentration (liquid water accumulation in gas channel and gas diffusion layer (GDL) as well as relative humidity in PEM and catalyst layer) and required $\mathrm{O}_{2}$ supply in order to obtain a good power generation performance of PEFC under relatively higher temperature operating conditions than usual.
\end{abstract}

Key words : Polymer electrolyte fuel cell (PEFC), Higher temperature operation than usual, Temperature distribution, Thermograph, Impact of operation condition, Power generation performance

\section{Introduction}

Polymer Electrolyte Fuel Cell (PEFC) has many attractive features including high power density, quick start-up and relatively high energy conversion efficiency. The PEFC can also be utilized for power production in the integrated renewable energy system, where the energy storage is in the form of electrolytic hydrogen (Agbossou et al., 2004a). However, several technical obstacles hinder its widespread commercialization for transportation and stationary applications. Main technical constraints on operation of PEFC are inadequate water/humidity and heat management, intolerance to impurities such as CO, sluggish electrochemical cathode kinetics and their high cost (Zhang et al., 2006; Agbossou et al., 2004b). 
The current PEFC has Nafion membrane and PEFC is usually operated within the temperature range from $60{ }^{\circ} \mathrm{C}$ to $80{ }^{\circ} \mathrm{C}$ (Zhang and Kandlikar, 2012; Agbossou et al., 2004a). It is desired that PEFC operating temperature will be $90{ }^{\circ} \mathrm{C}$ for stationary applications during period from 2020 to 2030 in Japan (according to NEDO road map 2010 (NEDO, 2010)).The power generation of PEFC under relatively higher operating temperature has following merits: (i) enhancement of electro-chemical kinetics for both electrode reactions; (ii) simplification in the cooling system due to increase in temperature gradient between the PEFC stack and coolant; (iii) increase in tolerance of CO and allowing the PEFC to use lower quality reformed hydrogen (Li et al., 2003). To develop the PEFC system operated under high temperature condition, heat and mass transfer characteristics should be analyzed for power generation performance and system durability.

In this study, the PEFC's in-plane temperature distribution has more focus as the local hot spot causes thermal decomposition of the proton exchange membrane (PEM) and thermal stress may break the PEM (Wang et al., 2006; Tsuji, 2008). It is well known that the local temperature in PEFC is closely related to the local performance, since operational temperature has significant impacts on electrochemical reaction kinetics, while local current density determines the local heat generation rate and thus the local temperature. Furthermore, some critical occurrences in the PEFC; such as water flooding, membrane dehydration, and even cell failure due to overheating; depend on both local temperature and local current density (Zhang et al, 2010). Although many studies have measured the temperature distribution in a single cell of PEFC using thermocouples (Zhang et al, 2010; Jiao et al, 2011; Lee et al., 2011; Zhang et al., 2012; Mizutani et al, 2014), a non-contact and in situ measurement method is promising in order to measure the temperature distribution in the cell more accurately without disturbing the heat and mass transfer phenomena during PEFC power generation. In the literatures (Hakenjos et al., 2004; Ogawa et al, 2004a; Wang et al, 2006), it was reported that the results on temperature distribution (measured by non-contact thermograph) were lower in the range up to $60{ }^{\circ} \mathrm{C}$ under dry gases supply. In the literature, it was not reported any analysis on the temperature distribution measurement within the temperature range from even $70{ }^{\circ} \mathrm{C}$ to $80{ }^{\circ} \mathrm{C}$. To observe the temperature distribution, the insertion of thermocouples can influence the power generation performance and temperature measurement accuracy remarkably due to leakage in the gases (Ogawa et al, 2003; Ogawa et al, 2004b).

In our previous work (Nishimura et al, 2011a, 2011b; Nishimura et al, 2012), it was reported the temperature distribution on the backside of separator at the cathode of single cell of PEFC at operation temperature of $70{ }^{\circ} \mathrm{C}$ using thermograph, and it's observation window made by holing end block, current collector and hot water passage plate. The in-plane temperature distribution could be measured accurately without the influence of absorbing the infrared rays by water droplet and assembly pressure of the glass window, since the glass window was not installed inside the cell.

In the reference (Zhang et al, 2010), it was reported that the cell temperature and the current density distribution measurements were similar under different flow rate of supply gases. Also the output voltage was changed when the operating temperature was decreased as well as the decrease in the current density (Zhang et al, 2010). In reference (Zhang et al, 2010), the temperature was measured using thermocouples placed on the interface between catalyst layer and gas diffusion layer (GDL) at the cathode and the current density was measured on the interface between the GDL and separator at the anode by gasket technique. Though the temperature measurement area inside the cell was different from this study, this study found the similar trend between the reference and this study, that is, the power was high when the measured temperature was high. Therefore, it is thought that the temperature distribution data at the separator obtained by this study can be used for the prediction of power generation performance.

Through literature survey, it has been observed that the in-plane temperature distribution under relatively higher temperature operation up to $90{ }^{\circ} \mathrm{C}$ has not been investigated yet. Also quantitative evaluations on in-plane temperature distribution have not been carried out for broader temperature range. In addition, the operating conditions such as relative humidity of supply gases have also not been investigated under relatively higher temperature operations yet.

Objective of this study is to analyze the impact of operation condition on temperature distribution in single cell of PEFC under higher temperature operation such as $90{ }^{\circ} \mathrm{C}$ and $100{ }^{\circ} \mathrm{C}$. In this study, Nafion 115 , which was used in a typical PEM operated within the temperature range from $60{ }^{\circ} \mathrm{C}$ to $80{ }^{\circ} \mathrm{C}$, was used in order to evaluate the performance characteristics under relatively higher temperature operational condition. After checking the problem of the current PEM, this study would like to propose appropriate operation and design techniques of PEM, which has to be adopted for relatively higher temperature operation. The in-plane temperature distributions on backside of gas separator of cell at the anode and the cathode were measured using thermograph, under power generation with varying initial operational temperature of the cell (which was equal to the temperature of supply gases at inlet), relative humidity of 
supply gases, and the cathode gas type. The voltage, load current and load impedance were also analyzed for performance analysis of PEFC.

\section{Nomenclature}

$\begin{array}{lll}C_{\mathrm{H} 2}: & \text { Molar flow rate of supplied } \mathrm{H}_{2} & {[\mathrm{~mol} / \mathrm{s}]} \\ C_{\mathrm{O} 2}: & \text { Molar flow rate of supplied } \mathrm{O}_{2} & {[\mathrm{~mol} / \mathrm{s}]} \\ F: & \text { Faraday constant }(=96500) & {[\mathrm{C} / \mathrm{mol}]} \\ I: & \text { Load current } & {[\mathrm{A}]} \\ n: & \text { Valence ion }(=2) & {[-]} \\ T_{\text {ave }}: & \text { Average temperature in observation area } & {\left[{ }^{\circ} \mathrm{C}\right]} \\ T_{\mathrm{i}}: & \text { Average temperature in each area } & {\left[{ }^{\circ} \mathrm{C}\right]} \\ T_{\text {ini }}: & \text { Initial operational temperature } & {\left[{ }^{\circ} \mathrm{C}\right]} \\ T_{\mathrm{PEM}}: & \text { Temperature of PEM cell } & {\left[{ }^{\circ} \mathrm{C}\right]} \\ \lambda: & \text { Water (humidity) content in PEM } & {\left[\mathrm{mol}-\mathrm{H}_{2} \mathrm{O} / \mathrm{mol}^{-\mathrm{SO}_{3}}{ }^{-}\right]} \\ \sigma: & \text { Proton conductivity of PEM } & {\left[\Omega / \mathrm{cm}^{2}\right.}\end{array}$

\section{PEFC experiment system}

\subsection{Experimental apparatus and procedure}

Single cell of PEFC (MC-25-SC-NH, Reactive Innovations) was used in this study. The specifications of components of single cell of PEFC are given in Table 1. In-plane temperature measurements procedure of single cell of PEFC is shown in Fig. 1. The width and height of the observation window, which were equal to those of the electrode, were $50 \mathrm{~mm}$ and $50 \mathrm{~mm}$, respectively. To prevent gas leak, the width and height of hole made in hot water passage plate was set at $40 \mathrm{~mm}$ and $50 \mathrm{~mm}$, respectively.

Table 1 Specifications of components of single cell of PEFC.

\begin{tabular}{|c|c|c|}
\hline Parts & Size & Characteristics \\
\hline PEM & $50.0 \mathrm{~mm} \times 50.0 \mathrm{~mm} \times 0.13 \mathrm{~mm}$ & $\begin{array}{c}\text { Nafion } 115 \\
\text { (produced by Du Pont. Corp.) }\end{array}$ \\
\hline Catalyst layer & $\begin{array}{c}50.0 \mathrm{~mm} \times 50.0 \mathrm{~mm} \\
\text { (attached with PEM) }\end{array}$ & Pt/C (20 wt\% Pt loading) \\
\hline GDL & $50.0 \mathrm{~mm} \times 50.0 \mathrm{~mm} \times 0.17 \mathrm{~mm}$ & $\begin{array}{l}\text { TGP-H060 (Carbon paper) } \\
\text { (produced by Toray Corp.) }\end{array}$ \\
\hline Separator & $\begin{array}{c}75.4 \mathrm{~mm} \times 75.4 \mathrm{~mm} \times 2.00 \mathrm{~mm} \\
\text { (Gas supply area: } 50.0 \mathrm{~mm} \times 50.0 \mathrm{~mm} \text { ) }\end{array}$ & Carbon graphite, Serpentine \\
\hline Hot water passage plate & $75.4 \mathrm{~mm} \times 75.4 \mathrm{~mm} \times 2.00 \mathrm{~mm}$ & Carbon graphite \\
\hline Current collector & Area: $6937 \mathrm{~mm}^{2}$, Thickness: $2.00 \mathrm{~mm}$ & Copper coated with gold \\
\hline End block & $110 \mathrm{~mm} \times 110 \mathrm{~mm} \times 12.7 \mathrm{~mm}$ & Aluminum \\
\hline
\end{tabular}

The in-plane temperature distribution on the backside of separator at the anode or cathode was measured through the observation window using thermograph (Thermotracer TH9100WL, NIPPON AVIONICS CO., LTD.) and analyzed (TH91-702, NIPPON AVIONICS CO., LTD.). To minimize the measurement error caused by roughness and reflection of separator surface, a black body tape (HB-250, OPTIX) with thickness of $0.1 \mathrm{~mm}$, was fitted on the backside of 
separator. The emissivity of this black body tape under this experimental condition was measured prior to the experiment. The impact on power generation output due to the observation window was very little. The pre-experiment condition was taken as the initial operational temperature of cell at $70{ }^{\circ} \mathrm{C}$ and the relative humidity of supply gas at $80 \% \mathrm{RH}$ (with and without observation window). During the pre-experiment condition, voltages at the current density of $0.80 \mathrm{~A} / \mathrm{cm}^{2}$ for the anode and cathode observation were decreased only by $4 \%$ and $7 \%$, respectively. It was observed that the influence of the observation window on the performance of PEFC could be negligible.

In the experimental set-up, all sides of the cell, except observation window side and the opposite side to observation window, were thermally insulated. To measure the in-plane temperature distribution caused by reaction heat, the single cell was operated at high load current density of $0.80 \mathrm{~A} / \mathrm{cm}^{2}$ except some conditions, when the in-plane temperature distribution was measured using thermograph. Under this condition, the temperature of single cell was able to maintain over the set initial operation temperature without heating by silicon rubber heater. In other words, the cell could maintain the temperature over the initial temperature with the heat generated by electrochemical reaction without external heat input. In addition, if we can suggest the improvement way of power generation performance at high current density, the stack of PEFC can be more compacted due to realization of relatively higher power generation density. According to the manufacturer, the thermal conductivities of PEM, GDL and separator are $0.195 \mathrm{~W} /(\mathrm{m} \cdot \mathrm{K}), 1.7$ $\mathrm{W} /(\mathrm{m} \cdot \mathrm{K})$ and $25 \mathrm{~W} /(\mathrm{m} \cdot \mathrm{K})$, respectively. Meanwhile, the thermal conductivities of hot water passage plate, current collector and end block are $25 \mathrm{~W} /(\mathrm{m} \cdot \mathrm{K}), 380 \mathrm{~W} /(\mathrm{m} \cdot \mathrm{K})$ and $220 \mathrm{~W} /(\mathrm{m} \cdot \mathrm{K})$, respectively. Since the thermal conductivities of hot water passage plate, current collector and end block, which were located outside of separator, had more than those of PEM, GDL and separator, it was observed that the impact of ambient air on temperature distribution was negligible. In this study, since the gas leak had been occurred without hot water passage plate, which was assembled in a commercial cell in advance, the hot water passage plate was used for preventing gas leak without flowing hot water.
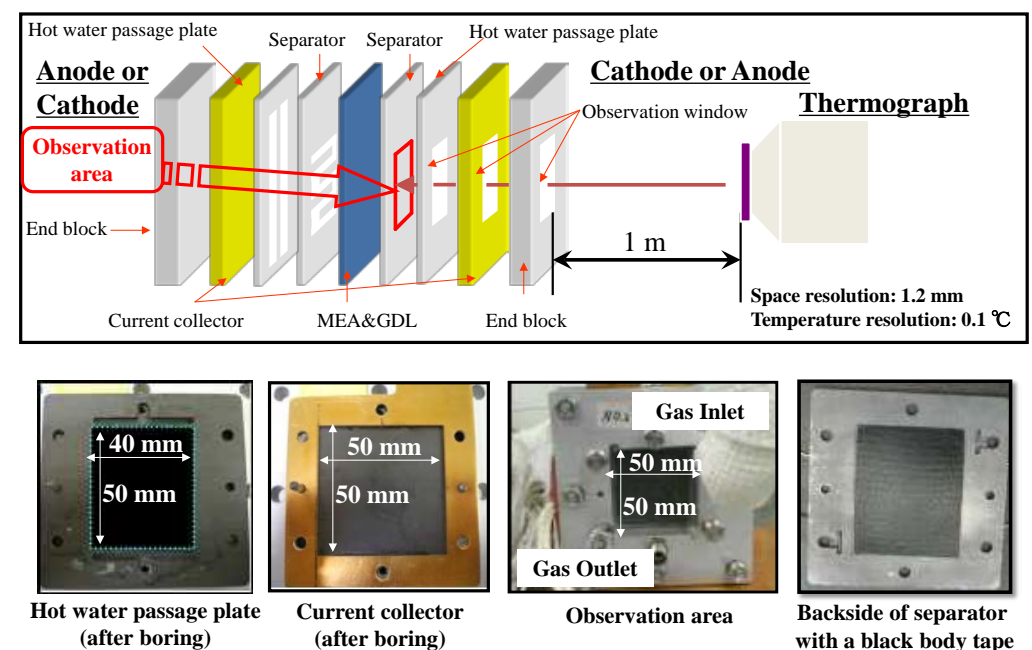

Fig. 1 Temperature measurement procedure of single cell of PEFC with observation window.

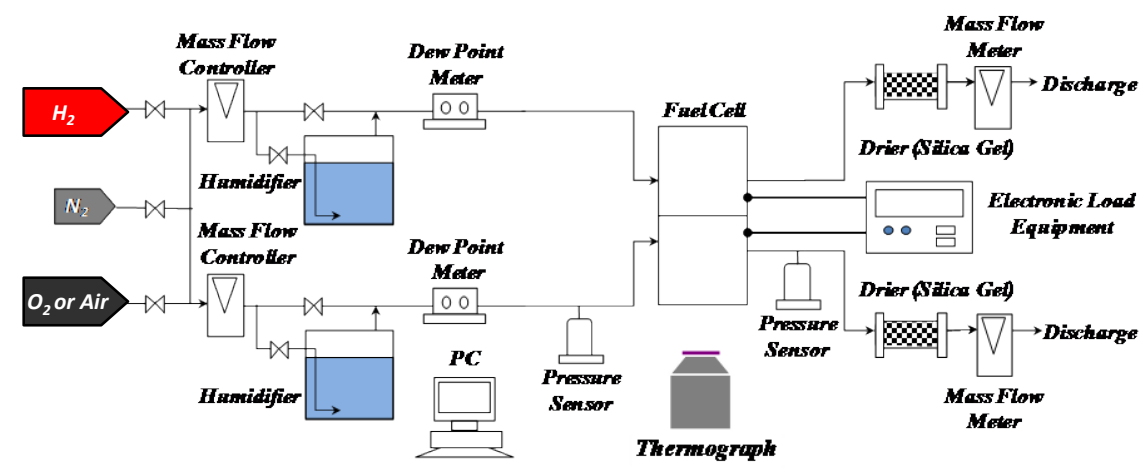

Fig. 2 Schematic drawing of experimental set-up. 
The experimental conditions and parameters are given in Table 2. Initial operational temperature of cell ( $\left.T_{\text {ini }}\right)$ was changed from $80{ }^{\circ} \mathrm{C}$ to $100{ }^{\circ} \mathrm{C}$ for investigating the heat and mass transfer characteristics. The temperature of supply gases at the inlet of the cell was controlled to be the same as $T_{\text {ini. }}$ The relative humidity of the supply gases at the inlet of the cell was changed from $40 \% \mathrm{RH}$ to $100 \% \mathrm{RH}$ (at the anode and cathode were set for the same relative humidity). The relative humidity of supply gases was managed using a humidifier and a dew point meter (HMT337FC, VAISALA). The flow rates of supply gases, which were pure $\mathrm{H}_{2}$ for the anode and pure $\mathrm{O}_{2}$ for the cathode, were set at the stoichiometric ratio of 3.0. The flow rates of supply gases at the inlet of the cell were controlled through the mass flow controller (5850E, BROOKS INSTRUMENT). The flow rates of supply gas, which equals to the stoichiometric ratio of 1.0, is decided from Eq. (1).

$$
C_{H_{2}}=\frac{I}{n \times F}
$$

where $C_{\mathrm{H} 2}$ is the molar flow rate of supplied $\mathrm{H}_{2}[\mathrm{~mol} / \mathrm{s}], I$ is the load current $[\mathrm{A}]=[\mathrm{C} / \mathrm{s}], n$ is the valence ion $(=2)$ [-], $F$ is Faraday constant $(=96500)[\mathrm{C} / \mathrm{mol}] . C_{\mathrm{H} 2}$ equals to the amount of supplied $\mathrm{H}_{2}$ of the stoichiometric ratio of 1.0. $C_{\mathrm{O} 2}$ which is the molar flow rate of supplied $\mathrm{O}_{2}[\mathrm{~mol} / \mathrm{s}]$ is calculated by Eq. (2):

$$
\mathrm{H}_{2}+1 / 2 \mathrm{O}_{2}=\mathrm{H}_{2} \mathrm{O}
$$

\begin{tabular}{|c|c|c|}
\hline Initial operation temperature of cell $\left(T_{\text {ini }}\right)\left[{ }^{\circ} \mathrm{C}\right]$ & \multicolumn{2}{|c|}{$80,90,100$} \\
\hline $\begin{array}{c}\text { Load current of cell }[\mathrm{A}] \\
\text { (Current density of cell }\left[\mathrm{A} / \mathrm{cm}^{2}\right] \text { ) }\end{array}$ & \multicolumn{2}{|c|}{$\begin{array}{c}20 \\
(0.80)\end{array}$} \\
\hline \multicolumn{3}{|c|}{ Supply gas conditions } \\
\hline & Anode & Cathode \\
\hline Gas type & $\begin{array}{c}\mathrm{H}_{2} \\
\text { (purity: 99.995 vol\%) }\end{array}$ & $\begin{array}{c}\mathrm{O}_{2} \\
\text { (purity: 99.995 vol\%) }\end{array}$ \\
\hline Temperature of supply gas at inlet $\left[{ }^{\circ} \mathrm{C}\right]$ & $80,90,100$ & $80,90,100$ \\
\hline Relative humidity of supply gas at inlet [\%RH] & $40,60,80,100$ & $40,60,80,100$ \\
\hline $\begin{array}{l}\text { Pressure of supply gas } \\
\text { at inlet (absolute) [MPa] }\end{array}$ & 0.4 & 0.4 \\
\hline $\begin{array}{l}\text { Flow rate of supply gas at inlet [NL/min] } \\
\text { (Stoichiometric ratio) }\end{array}$ & $\begin{array}{l}0.420 \\
(3.0)\end{array}$ & $\begin{array}{l}0.210 \\
(3.0)\end{array}$ \\
\hline
\end{tabular}

Table 2 Experimental conditions.

In the experimental set-up, the load current of PEFC was controlled through the electric load (PLZ603W, KIKUSUI ELECTRONICS CORP.). Load voltages with reference to the current density and the load impedance were measured using the electric load and the impedance meter (KFM2030, KIKUSUI ELECTRONICS CORP.).

In this study, single cell was heated for start-up using the silicon rubber heater (Silicon rubber heater MG, OM Heater), which was set up around the end block. In this start-up process, $\mathrm{H}_{2}$ and $\mathrm{O}_{2}$ were also heated at $T_{\text {ini }}$ before supplying to the cell. After attaining the cell temperature at $T_{\text {ini, }}$ the power generation was started and changed through the load variation. Under the steady state loading conditions, flow rate of supply gases at the inlet and outlet of the cell, temperature distribution (measured using the thermograph) were kept steady state over $30 \mathrm{~min}$. It was observed that the measurements errors of temperature under different experimental condition were below $0.2{ }^{\circ} \mathrm{C}$.

\subsection{Temperature data analysis}

In this study, in-plane temperature distribution image obtained by using the thermograph was analyzed by segmented evaluation of cross sectional area. The in-plane temperature distribution image was divided into the area, 
whose vertical and horizontal length were $10 \mathrm{~mm}$ and $10 \mathrm{~mm}$, respectively (Fig. 3). These 20 areas were named from A to $\mathrm{T}$ followed by the gas flow through gas channel. The temperature averaged in each area was obtained. As to the areas of $\mathrm{A}$ and $\mathrm{T}$, the temperature was averaged in the area, where the insulator covering the gas pipe did not disturb the detection of infrared ray by the thermograph.

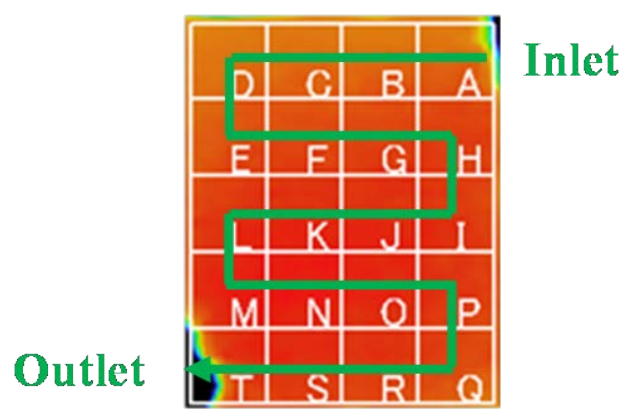

Fig. 3 Segmented evaluation of in-plane temperature distribution.

To evaluate the in-plane temperature distribution under the different operation conditions quantitatively, the temperature difference $T_{\mathrm{i}}-T_{\text {ave }}\left[{ }^{\circ} \mathrm{C}\right]$ has been used, where $T_{\mathrm{i}}$ is the average temperature in each area $\left[{ }^{\circ} \mathrm{C}\right]$ and $T_{\text {ave }}$ is the average temperature in observation area $\left[{ }^{\circ} \mathrm{C}\right]$.

\section{Results and discussion}

\subsection{Power generation performance analysis}

Table 3 lists the average total voltage for each experimental condition. "The average total voltage" means the total voltage of the single cell obtained by averaging the data during the steady state power generation period of a few minutes for specific power output operating condition. At the $T_{\text {ini }}$ of $90{ }^{\circ} \mathrm{C}$ and $100{ }^{\circ} \mathrm{C}$, the power generation at the relative humidity of supply gas of $40 \% \mathrm{RH}$ was not carried out at the current density of $0.80 \mathrm{~A} / \mathrm{cm}^{2}$, resulting that the total voltages obtained under the limits of current density of $0.72 \mathrm{~A} / \mathrm{cm}^{2}$ and $0.52 \mathrm{~A} / \mathrm{cm}^{2}$ are shown in Table 3 . In addition, the power generation under the condition that the relative humidity of supply gas at $100 \%$ RH was not carried out at $T_{\text {ini }}$ of $100{ }^{\circ} \mathrm{C}$ due to operational limitations of the experimental system.

It was observed that the average total voltage decreased with decrease in relative humidity of supply gases

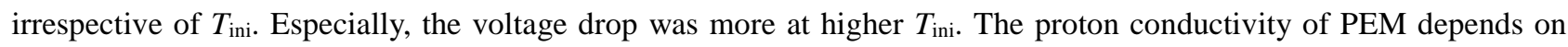
water content in Nafion membrane, which is shown in Eq. (3) (Springer et al., 1991) and it decreases with decrease in relative humidity of supply gases.

$$
\sigma=(0.005139 \lambda-0.00326) \exp \left\{1268\left(\frac{1}{303}-\frac{1}{273+T_{P E M}}\right)\right\}
$$

where $\sigma$ is the proton conductivity of PEM $[\Omega / \mathrm{cm}], \lambda$ is the water content in PEM $\left[\mathrm{mol}-\mathrm{H}_{2} \mathrm{O} / \mathrm{mol}^{-\mathrm{SO}_{3}}{ }^{-}\right], T_{\mathrm{PEM}}$ is the temperature of PEM $\left[{ }^{\circ} \mathrm{C}\right]$. Due to the decrease in proton conductivity of PEM, the membrane resistance, which was calculated by using the impedance data (Kim et al., 2013) obtained in this work, was increased (Table 4). It was noticed that the average total voltage decreased under lower relative humidity conditions. At higher $T_{\text {ini, }}$ the saturated vapor pressure is increased exponentially (Fig. 4) (The Engineering ToolBox, 2015). Since the cell was heated by power generation, the cell temperature during power generation was higher than the temperature of supply gases. If the temperature elevation is the same among the different $T_{\text {ini }}$ conditions, the actual relative humidity in the cell decreases with increase in $T_{\text {ini }}$ due to the exponential increase in saturation vapor pressure. The water generation rate also affects the actual relative humidity in the cell. According to Table 4, the membrane resistance increased with increase in $T_{\text {ini, }}$ indicating the decrease in water content ratio to the capacity of vapor amount to contain in gas in the cell. Therefore, it is considered that the water content ratio to the capacity of vapor amount to contain in gas in the cell decreased with increase in $T_{\text {ini, }}$, resulting that the total voltage decreased. 
Table 3 Comparison of PEFC power generation performance.

\begin{tabular}{|c|c|c|c|c|c|c|c|c|c|c|c|}
\hline \multicolumn{4}{|c|}{$80{ }^{\circ} \mathrm{C}$} & \multicolumn{5}{c|}{$90{ }^{\circ} \mathrm{C}$} & \multicolumn{4}{c|}{$100{ }^{\circ} \mathrm{C}$} \\
\hline $40 \% \mathrm{RH}$ & $60 \% \mathrm{RH}$ & $80 \% \mathrm{RH}$ & $100 \% \mathrm{RH}$ & $40 \% \mathrm{RH}$ & $60 \% \mathrm{RH}$ & $80 \% \mathrm{RH}$ & $100 \% \mathrm{RH}$ & $40 \% \mathrm{RH}$ & $60 \% \mathrm{RH}$ & $80 \% \mathrm{RH}$ & $100 \% \mathrm{RH}$ \\
\hline $0.363 \mathrm{~V}$ & $0.492 \mathrm{~V}$ & $0.535 \mathrm{~V}$ & $0.555 \mathrm{~V}$ & $0.261 \mathrm{~V}$ & $0.451 \mathrm{~V}$ & $0.517 \mathrm{~V}$ & $0.542 \mathrm{~V}$ & $0.154 \mathrm{~V}$ & $0.362 \mathrm{~V}$ & $0.415 \mathrm{~V}$ & - \\
\hline
\end{tabular}

Table 4 Comparison of membrane resistance calculated by using the impedance data.

\begin{tabular}{|c|c|c|c|c|c|c|c|c|c|c|c|}
\hline \multicolumn{4}{|c|}{$80{ }^{\circ} \mathrm{C}$} & \multicolumn{5}{c|}{$90{ }^{\circ} \mathrm{C}$} & \multicolumn{4}{|c}{$100{ }^{\circ} \mathrm{C}$} \\
\hline $40 \% \mathrm{RH}$ & $60 \% \mathrm{RH}$ & $80 \% \mathrm{RH}$ & $100 \% \mathrm{RH}$ & $40 \% \mathrm{RH}$ & $60 \% \mathrm{RH}$ & $80 \% \mathrm{RH}$ & $100 \% \mathrm{RH}$ & $40 \% \mathrm{RH}$ & $60 \% \mathrm{RH}$ & $80 \% \mathrm{RH}$ & $100 \% \mathrm{RH}$ \\
\hline $15.68 \mathrm{~m} \Omega$ & $10.53 \mathrm{~m} \Omega$ & $7.91 \mathrm{~m} \Omega$ & $8.07 \mathrm{~m} \Omega$ & $21.00 \mathrm{~m} \Omega$ & $12.61 \mathrm{~m} \Omega$ & $8.76 \mathrm{~m} \Omega$ & $7.65 \mathrm{~m} \Omega$ & $18.51 \mathrm{~m} \Omega$ & $13.92 \mathrm{~m} \Omega$ & $11.34 \mathrm{~m} \Omega$ & - \\
\hline
\end{tabular}

When the relative humidity of supply gas was $40 \% \mathrm{RH}$ at $T_{\text {ini }}$ of $100{ }^{\circ} \mathrm{C}$, the power generation itself could not be carried out at the same current density as the other $T_{\text {ini }}$ due to severe dehydration condition.

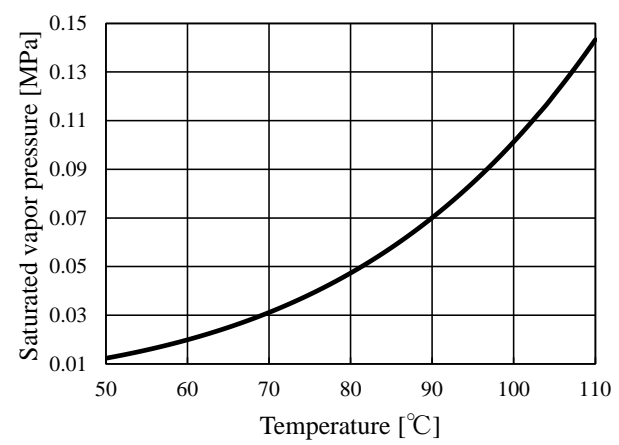

Fig. 4 Relationship between saturated vapor pressure and temperature.

\subsection{Analysis on in-plane temperature distribution}

Figures 5, 6 and 7 show the in-plane temperature distribution at the anode under various relative humidity of supply gases. The local temperature deviations to the average value, $T_{\mathrm{i}}-T_{\text {ave, }}$ are plotted for $T_{\text {ini }}$ of $80{ }^{\circ} \mathrm{C}, 90{ }^{\circ} \mathrm{C}$ and $100{ }^{\circ} \mathrm{C}$, respectively. In-plane temperature distribution at the cathode for various relative humidity of supply gases are given in Figs. 8, 9 and 10 and the local temperature deviations to the average value, $T_{\mathrm{i}}-T_{\text {ave }}$, are plotted for $T_{\text {ini }}$ of $80{ }^{\circ} \mathrm{C}, 90{ }^{\circ} \mathrm{C}$ and $100{ }^{\circ} \mathrm{C}$, respectively.

Comparing the in-plane temperature distribution at the anode with that at the cathode, the in-plane temperature distribution at the anode was more even than that at the cathode irrespective of relative humidity of supply gas except $T_{\text {ini }}$ of $100{ }^{\circ} \mathrm{C}$. The thermal conductivity of $\mathrm{H}_{2}$ is higher than that of $\mathrm{O}_{2}$ (Japan Society Mechanical Engineers, 1993). In this work, the flow rate of $\mathrm{H}_{2}$ was higher than that of $\mathrm{O}_{2}$ (Table 2). Therefore, it was considered that the convection heat transfer at the anode might be better than at the cathode. Additionally, it was considered that water produced by electrochemical reaction as well as humidification water in the gas for supply to the cell existed at the cathode. The heat generation by condensation of water, the heat retained by sensible heat of water droplet and decrease in power generation due to gas diffusion inhibition by liquid water might have been occurred. Consequently, the local temperature gradient might have become larger at the cathode. Considering the temperature distribution along gas flow through gas channel, it was observed that the temperature dropped at the areas of L and Q (Fig. 3) for the anode as well as the cathode. Since these areas were located at the corner of serpentine channel, the liquid waters were might have been remaining there (Quan et al., 2005; Quand and Lai, 2007). It might have been due to the occurrence of liquid water accumulation in GDL and gas channel. Consequently, the decrease in power generation due to gas diffusion inhibition by remains of liquid water might have been occurred at these areas. According to the reference (Jiao et al., 2010), experimental observation of water behavior in GDL and gas channel, the cross flow in GDL might have been occurred under the rib area for removing water droplets while the water droplets in the channel are removed by the gas flow.

In this work, the distribution of vapor and liquid water was not observed in the cell directly, but it was considered 
that the temperature distribution might have been affected by the behavior of vapor and liquid water. Since it was observed that the temperature elevation at the parts of straight channel, such as the areas of $\mathrm{N}$ and S, it could be thought that the gas was provided well in these areas. It was believed that the gas short cut through GDL occurred to conduct the power generation in the areas where the gas could pass through without big resistance. At the area of $\mathrm{H}$ located at the corner of serpentine channel, the temperature was not dropped. Since the area of $\mathrm{H}$ was located at the first half of serpentine separator, it was believed that liquid water accumulation was not so much compared to the last half of serpentine separator and such water distribution observation by neutron imaging was reported in reference (Zhang et al., 2006). PEM was hydrated by the produced water by electrochemical reaction with gas flow from the inlet through gas channel. In addition, the excess gas which was not reacted, might have been heated by the electrochemical reaction from the inlet through gas channel. Therefore, the temperature might have been increased along gas channel from the inlet including the area of $\mathrm{H}$. However, in the last half of serpentine separator, the temperature might have been dropped at the corner of serpentine channel as liquid water accumulation might have been more. Regarding the area of $\mathrm{D}$, it was the opposite side through the cell was located at the inlet of gas flow whose temperature was colder than the cell temperature, resulting in the temperature drop.

Since liquid water might not be generated in the cell due to the high saturation vapor pressure at $T_{\text {ini }}$ of $100{ }^{\circ} \mathrm{C}$, the wider in-plane temperature distribution as described above was not observed. However, the in-plane temperature distribution at the anode for $T_{\text {ini }}$ of $100{ }^{\circ} \mathrm{C}$ became wider compared to the other $T_{\text {ini. }}$ It might have been easy to be dehydrated especially in the anode side. Since the water was produced by electrochemical reaction at the cathode, it was believed that the water concentration difference between the anode and the cathode might have become higher at $T_{\text {ini }}$ of $100{ }^{\circ} \mathrm{C}$. In addition, the gas which was not consumed for the electrochemical reaction might have been heated by the reaction heat along gas channel. It might have heated more at $T_{\text {ini }}$ of $100{ }^{\circ} \mathrm{C}$ due to higher temperature operating condition. Therefore, the areas from Q to T might have been dehydrated compared to the areas from F to K. As a result, the electrochemical reaction from the areas of $\mathrm{F}$ to $\mathrm{K}$ might have been better than that from the areas of Q to T. It can be said that the anode can be easy to get dehydrated compared to the cathode due to water produced by electrochemical reaction. The liquid water can be easy to stay at the corner of serpentine channel at the anode as well as the cathode. Therefore, the water concentration difference between the anode and the cathode was smaller at the corner of serpentine channel, resulting that the back diffusion of water might have not been occurred. As to the areas of $\mathrm{M}$ and $\mathrm{Q}$, the temperature was dropped as liquid water might have been easy to be stayed at the corner of serpentine channel due to the friction of bended channel even at $T_{\text {ini }}$ of $100{ }^{\circ} \mathrm{C}$. Regarding $\mathrm{D}$, the opposite side through the cell, located at the inlet of gas flow, whose temperature was relatively lower than the cell temperature, resulting in temperature drop. On the other hand, the straight parts of serpentine channel such as the areas of $\mathrm{F}$ and $\mathrm{K}$ at the anode might have been dehydrated, while those at the cathode might have been hydrated with water produced due to electrochemical reaction. Therefore, the water concentration difference between the straight parts at the anode and those at the cathode might have been large, resulting that the back diffusion of water occurred more. It was believed that the temperature distributions at the anode and the cathode might have been obtained after these back diffusion of water occurred. Consequently, the water distribution at the anode was larger than that at the cathode, which was caused the wider temperature distribution at the anode and the even temperature distribution at the cathode.

Through the analysis of the in-plane temperature distributions at the cathode, it was observed that $T_{\mathrm{i}}-T_{\text {ave }}$ was increased along the gas flow through gas channel from the inlet to the outlet except $T_{\text {ini }}$ of $100{ }^{\circ} \mathrm{C}$. When the gas was flowing through gas channel toward the outlet of cell, the gas and PEM were humidified with the produced water through electrochemical reaction (Lee et al., 2011). Then, the PEFC power generation performance increased toward the outlet of the cell, resulting in the increase in temperature near the outlet of cell. The impact of relative humidity of supply gases on the in-plane temperature distribution was analyzed and observed that, the temperature increased through gas channel toward the outlet of cell for the relative humidity of supply gas of $100 \%$ RH at $T_{\text {ini }}$ of $90{ }^{\circ} \mathrm{C}$, while the temperature increase was relatively smaller at $T_{\text {ini }}$ of $80{ }^{\circ} \mathrm{C} . T_{\text {ini }}$ of $90{ }^{\circ} \mathrm{C}$ was high temperature condition, resulting that the actual relative humidity in PEM or catalyst layer became lower even if the relative humidity of supply gas was high such as $100 \%$ RH. Therefore, the liquid water was not produced at $T_{\text {ini }}$ of $90{ }^{\circ} \mathrm{C}$ well compared to $T_{\text {ini }}$ of $80{ }^{\circ} \mathrm{C}$. Though the relative humidity of supply gases was managed before the inlet of the cell, but the relative humidity in PEM or catalyst layer might have been changed according to the power generation characteristics as well as heat and mass transfer characteristics. It is assumed that the concentration of humidified water in the supply gas keeps a constant from the inlet of the cell, and the actual relative humidity in PEM or catalyst layer is defined on the basis of comparison 
with the relative humidity of supply gas at the inlet of the cell. The gas diffusion inhibition by liquid water accumulation was smaller at $T_{\text {ini }}$ of $90{ }^{\circ} \mathrm{C}$ compared to $T_{\text {ini }}$ of $80{ }^{\circ} \mathrm{C}$, resulting that PEM might have been hydrated with the water in gas flow through gas channel. Consequently, the temperature increased through gas channel at $T_{\text {ini }}$ of $90{ }^{\circ} \mathrm{C}$. From Fig. 10, it could be observed that the in-plan temperature was relatively even distribution at $T_{\text {ini }}$ of $100{ }^{\circ} \mathrm{C}$ irrespective of the relative humidity of supply gas. However, the liquid water can be easily stayed at the corner of serpentine channel due to the friction of bended channel even at $T_{\text {ini }}$ of $100{ }^{\circ} \mathrm{C}$, resulting that the temperature was decreased due to gas diffusion inhibition by liquid water.

The in-plane temperature distributions at the anode were investigated for the impact of different $T_{\text {ini. }}$ It was noticed that the in-plane temperature distribution had little difference for $T_{\text {ini }}$ of $80{ }^{\circ} \mathrm{C}$ and $90{ }^{\circ} \mathrm{C}$. However, wider temperature distribution was observed at $T_{\text {ini }}$ of $100{ }^{\circ} \mathrm{C}$ irrespective of relative humidity of supply gases though the in-plane temperature distribution at the cathode was even. As shown in Table 3, the power generation performance for $T_{\text {ini }}$ of $100{ }^{\circ} \mathrm{C}$ was not good than the other $T_{\text {ini }}$ conditions. The power generation performance can be improved by dissolving the bias of water distribution as well as gas flow when the temperature is controlled to be even. Therefore, it is believed that the in-plane temperature distribution at the anode should be kept uniform in order to obtain the good PEFC power generation performance.

For the investigation on the impact of the cathode gas type on temperature distribution, the in-plane temperature distribution for various relative humidity of supply gas are shown in Fig. 11 using $T_{\mathrm{i}}-T_{\text {ave }}$ under the air supply condition for $T_{\text {ini }}$ of $90{ }^{\circ} \mathrm{C}$ at the anode and the cathode. The effect of the flow rates of supply gases were investigated, and noticed that there was not significant impact of flow rates of supply gases. It was observed during the power generation at $T_{\text {ini }}=90{ }^{\circ} \mathrm{C}$ and $60 \% \mathrm{RH}$, the average total voltages at the stoichiometric ratio of $1.5,2.0$ and 3.0 were $0.14 \mathrm{~V}, 0.15 \mathrm{~V}$ and $0.16 \mathrm{~V}$, respectively. In addition, in the case of $T_{\text {ini }}=90{ }^{\circ} \mathrm{C}$ and at $80 \% \mathrm{RH}$, the average total voltages at the stoichiometric ratio of $1.5,2.0$ and 3.0 were $0.20 \mathrm{~V}, 0.21 \mathrm{~V}$ and $0.20 \mathrm{~V}$, respectively. During these operational conditions, the average total voltage did not increase with the increase in the stoichiometric ratio. During these PEFC operation conditions, $T_{\mathrm{i}}$ was high as well as it was poor $\mathrm{O}_{2}$ concentration due to air supply as cathode gas. Accordingly, the difference of temperature distribution with the stoichiometric was small. Therefore, Fig. 11 shows the result with the stoichiometric ratio of 3.0 as a representative data. In the experimental work, amount of $\mathrm{O}_{2}$ was kept the same between the air supply condition and the $\mathrm{O}_{2}$ supply condition, when the stoichiometric ratio was the same. In other words, the flow rate of supply gas under the air supply condition was larger by the amount of $\mathrm{N}_{2}$ compared to the $\mathrm{O}_{2}$ supply condition.

The in-plane temperature distribution at the cathode was more uniform compared to the $\mathrm{O}_{2}$ supply condition (Fig. 9 \& Fig. 11). The $\mathrm{O}_{2}$ concentration under the air supply condition was lower than that under the $\mathrm{O}_{2}$ supply condition due to $\mathrm{N}_{2}$. In addition, it was thought that the $\mathrm{O}_{2}$ concentration might have been lower in the last half part of the cell due to gas consumption by electrochemical reaction. Though it was considered that the gas and PEM were humidified with the water produced by electrochemical reaction through gas channel toward the outlet of cell, it was noticed that the power generation performance decreased due to the degradation of $\mathrm{O}_{2}$ reduction reaction in catalyst layer at the cathode due to decrease in $\mathrm{O}_{2}$ concentration. For example, the average total voltage for the relative humidity of supply gas of $60 \% \mathrm{RH}$, $80 \% \mathrm{RH}$ and $100 \% \mathrm{RH}$ at $T_{\text {ini }}$ of $90{ }^{\circ} \mathrm{C}$ were $0.16 \mathrm{~V}, 0.20 \mathrm{~V}$ and $0.15 \mathrm{~V}$, respectively, which were reduced due to lower $\mathrm{O}_{2}$ supply concentrations (Table 3).

On the other hand, the in-plane temperature distribution at the anode was broader compared to not only that at the cathode but also that at the anode under the $\mathrm{O}_{2}$ supply condition. It could be seen that the temperature was dropped in the latter part of the cell along gas channel toward the outlet of cell. As described above, it was considered that the degradation of the $\mathrm{O}_{2}$ reduction reaction in catalyst layer at the cathode due to decrease in $\mathrm{O}_{2}$ concentration might have been progressed in the latter part of the cell along gas channel toward the outlet of cell. Since the $\mathrm{H}_{2}$ oxidation reaction in catalyst layer at the anode, which couples with the $\mathrm{O}_{2}$ reduction reaction in catalyst layer at the cathode and the $\mathrm{O}_{2}$ reduction reaction is slower than the $\mathrm{H}_{2}$ oxidation reaction, it is believed that the $\mathrm{H}_{2}$ oxidation reaction in catalyst layer at the anode is influenced by the decrease in $\mathrm{O}_{2}$ concentration at the cathode side (Ju et al., 2005). Therefore, the power generation performance was decreased, resulting in the temperature drop at the anode.

The decrease in power generation performance with broader temperature distribution at the anode was verified under the air supply condition as well as the $\mathrm{O}_{2}$ supply condition. It was revealed that this phenomenon might have been caused by the decrease in water and $\mathrm{O}_{2}$ concentration at the cathode. In addition, it was noticed that the excess water might have caused the change in local temperature gradient. From these obtained results, it is necessary to control 
humidification properly through the gas channel and GDL. It is important to consider liquid water accumulation in gas channel and GDL as well as relative humidity in PEM and catalyst layer, and also to have supply of oxidant with required $\mathrm{O}_{2}$ concentration in order to obtain the good power generation performance of PEFC under relatively higher temperature operating conditions than usual. The separator channel geometry is also important in designing PEFC. It is also recommended that it is effective to install bypass at the corner of serpentine channel in order to prevent the gas diffusion inhibition by water accumulation.

To obtain the high power generation performance of PEFC (using Nafion membrane) under relatively higher temperature operating conditions, the humidification management of PEM is important. Though Nafion membrane could be used under the high temperature operation condition up to $T_{\text {ini }}$ of $100{ }^{\circ} \mathrm{C}$, the relative humidity of supply gases must be kept high. However, trouble caused by water condensation and gas diffusion inhibition by water droplet under the high temperature operation condition can be avoided. Consequently, it is expected that the management of heat and mass transfer in the cell of PEFC can become easier even though the relative humidity of supply gas is higher. If we want to operate the PEFC using Nafion membrane under the high temperature and low relative humidity operation condition, then the additional water management system is necessary, e.g. the reuse of water discharged from the outlet of the cell by recirculation pipe line. The water transfer from the cathode to the anode or the reverse by controlling the difference of relative humidity of supply gases between the cathode and the anode might be also available.

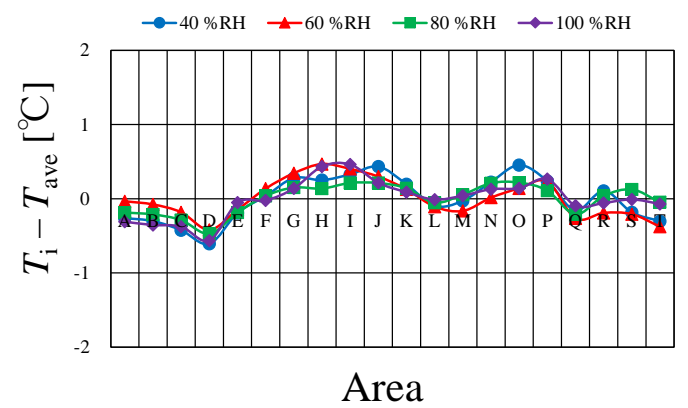

Fig. 5 In-plane temperature distribution at anode evaluated by $T_{\mathrm{i}}-T_{\text {ave }}\left(T_{\text {ini }}=80{ }^{\circ} \mathrm{C}\right)$.

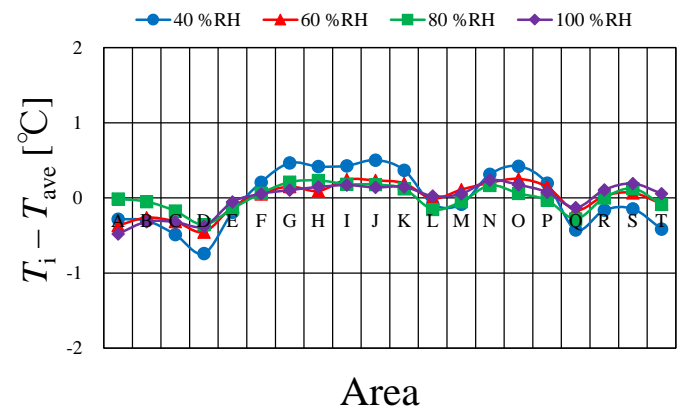

Fig. 6 In-plane temperature distribution at anode evaluated by $T_{\mathrm{i}}-T_{\text {ave }}\left(T_{\text {ini }}=90{ }^{\circ} \mathrm{C}\right)$.

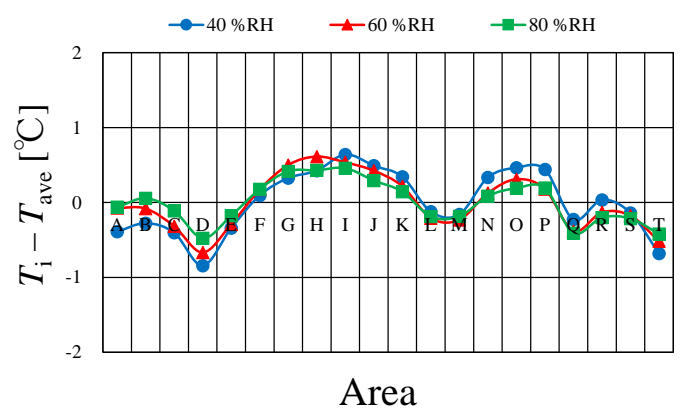

Fig. 7 In-plane temperature distribution at anode evaluated by $T_{\mathrm{i}}-T_{\text {ave }}\left(T_{\text {ini }}=100{ }^{\circ} \mathrm{C}\right)$. 


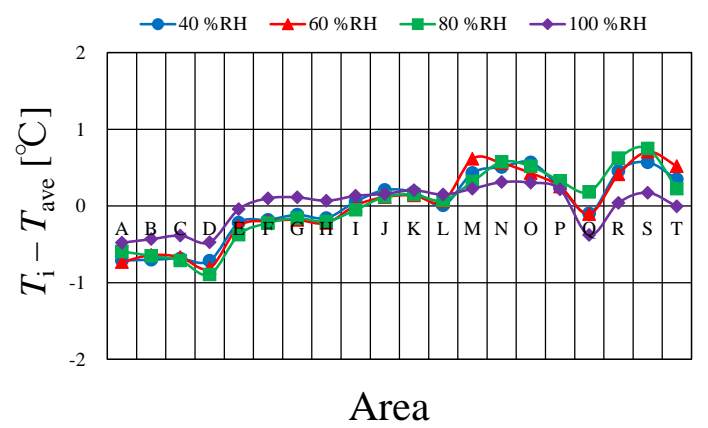

Fig. 8 In-plane temperature distribution at cathode evaluated by $T_{\mathrm{i}}-T_{\text {ave }}\left(T_{\text {ini }}=80{ }^{\circ} \mathrm{C}\right)$.

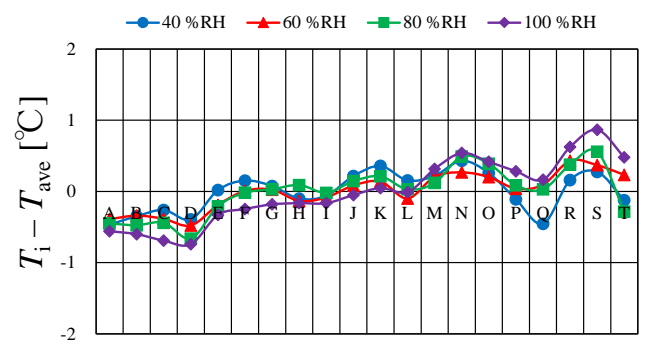

Area

Fig. 9 In-plane temperature distribution at cathode evaluated by $T_{\mathrm{i}}-T_{\text {ave }}\left(T_{\text {ini }}=90{ }^{\circ} \mathrm{C}\right)$.

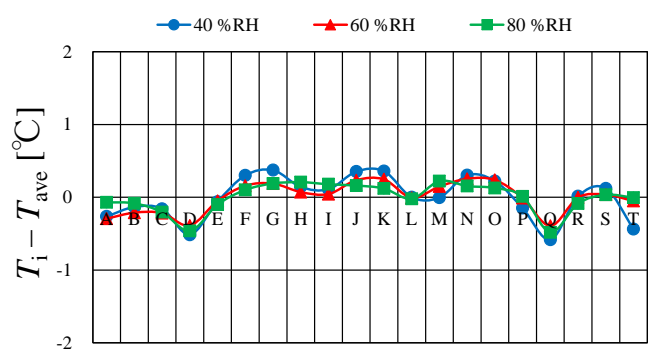

Area

Fig. 10 In-plane temperature distribution at cathode evaluated by $T_{\mathrm{i}}-T_{\text {ave }}\left(T_{\text {ini }}=100{ }^{\circ} \mathrm{C}\right)$.
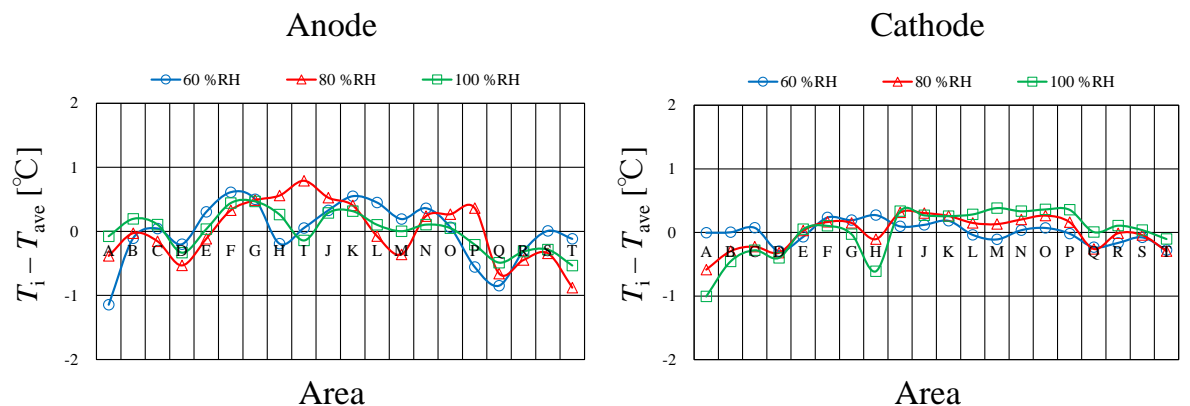

Area

Fig. 11 In-plane temperature distribution at anode and cathode evaluated by $T_{\mathrm{i}}-T_{\text {ave }}\left(\right.$ Air, $T_{\text {ini }}=90{ }^{\circ} \mathrm{C}$ ).

\section{Conclusion}

In this study, the impact of operational conditions such as $T_{\text {ini }}$, relative humidity of supply gases, and cathode gas type on temperature distribution on backside of gas separator in single cell of PEFC were analyzed under the power 
generation at relatively higher temperature. Based on the experimental results and their analysis, the following points are concluded.

(1) It was found that the average total voltage decreased with decrease in relative humidity of supply gas irrespective of $T_{\text {ini. }}$. The voltage drop was larger at higher $T_{\text {ini }}$ since the membrane resistance increased with increase in $T_{\text {ini. }}$.

(2) The in-plane temperature distribution at the anode was more uniform than at the cathode under the $\mathrm{O}_{2}$ supply condition irrespective of $T_{\text {ini }}$ and relative humidity of supply gas except at $T_{\text {ini }}$ of $100{ }^{\circ} \mathrm{C}$. The in-plane temperature distribution at the anode at $T_{\text {ini }}$ of $100{ }^{\circ} \mathrm{C}$ became broader compared to the other $T_{\text {ini. }}$.

(3) As the in-plane temperature distribution at the cathode under the $\mathrm{O}_{2}$ supply conditions, the temperature was increased through gas channel toward the outlet of cell for the relative humidity of supply gas of $100 \% \mathrm{RH}$ at $T_{\text {ini }}$ of $90{ }^{\circ} \mathrm{C}$, while the increase in temperature was relatively smaller at $T_{\text {ini }}$ of $80{ }^{\circ} \mathrm{C}$. The gas diffusion inhibition by liquid water accumulation was smaller at $T_{\text {ini }}$ of $90{ }^{\circ} \mathrm{C}$ compared to $T_{\text {ini }}$ of $80{ }^{\circ} \mathrm{C}$, resulting that PEM was hydrated with the water in gas flow through gas channel.

(4) The in-plane temperature distribution at the anode under the air supply conditions was broader compared to not only that at the cathode, but also that at the anode under the $\mathrm{O}_{2}$ supply conditions. Since the power generation performance was decreased due to the decrease in $\mathrm{O}_{2}$ concentration, and temperature dropped in the latter part of cell along gas channel toward the outlet of cell at the anode. In addition, the in-plane temperature distribution at the cathode was more uniform under the air supply condition compared to the $\mathrm{O}_{2}$ supply conditions. Since the $\mathrm{O}_{2}$ concentration was lower in the last half part of the cell due to gas consumption by electrochemical reaction, it was not observed that temperature has increased near the outlet of cell.

(5) It is concluded that it is important to control/manage water concentration considering, water accumulation in gas channel and GDL as well as relative humidity in PEM and catalyst layer, and supply of required $\mathrm{O}_{2}$ concentration properly in order to obtain the good power generation performance of PEFC under relatively higher temperature operating conditions than usual. The design of separator channel geometry is also important.

(6) To obtain the high power generation performance of PEFC using Nafion membrane under higher temperature operation conditions, the relative humidity of supply gases must be kept high.

(7) If we want to operate the PEFC using Nafion membrane under the high temperature and low relative humidity operation condition, the additional water management system is necessary.

\section{References}

Agbossou, K., Kolhe, M., Hamelin, J., Bose, T. K., Performance of a stand-alone renewable energy system based on energy storage as hydrogen, IEEE Transactions on Energy Conversion, Vol. 19 (2004a), pp. 633-640.

Agbossou, K., Kolhe, M., Hamelin, J., Bernier, E., Bose, T. K., Electrolytic hydrogen based renewable energy system with oxygen recovery and re-utilization, Renewable Energy, Vol. 29 (2004b), pp. 1305-1318.

Hakenjos, A., Muenter, H., Wittstadt, U. and Hebling C., A PEM fuel cell for combined measurement of current and temperature distribution, and flow filed flooding, Journal of Power Sources, Vol.131 (2004), pp.213-216.

Japan Society of Mechanical Engineers ed., JSME Heat Transfer Handbook (1993), p.387, Japan Society of Mechanical Engineers (in Japanese).

Jiao, K., Park, J. and Li, X., Experimental investigations on liquid water removal from the gas diffusion layer by reactant flow in a PEM fuel cell, Applied Energy, Vol.87 (2010), pp.2770-2777.

Jiao, K., Alaefour, I. E., Karimi, G. and Li, X., Simultaneous measurement of current and temperature distributions in a proton exchange membrane fuel cell during cold start processes, Electrochimica Acta, Vol.56 (2011), pp.2967-2982.

Ju, H., Meng, H. and Wang, C. Y., A single-phase, non-isothermal model for PEM fuel cells, International Journal of Heat and Mass Transfer, Vol.48 (2005), pp.130-1315.

Kim, J., Lee, I., Tak, Y. and Cho, B. H., Impedance-based diagnosis of polymer electrolyte membrane fuel cell failures associated with a low frequency ripple current, Renewable Energy, Vol.51 (2013), pp.302-309.

Lee, C. Y., Fan, W. Y. and Chang, C. P., A novel method for in-situ monitoring of local voltage, temperature and humidity distributions in fuel cells using flexible multi-functional micro sensors, Sensors, Vol.11 (2011), 
pp.1418-1432.

Li, Q., He, R., Jensen, J. O. and Bjerrum, N. J., Approaches and recent development of polymer electrolyte membrane for fuel cells operating above $100{ }^{\circ} \mathrm{C}$, Chemical of Materials, Vol.15, No.26 (2003), pp.4896-4915.

Mizutani, C., Kitahara, T., Nakajima, H., Sasaki, K. and Ito, K., Analysis of water behavior in PEFC through 3D thermal and temperature distribution measurement by ultrafine thermocouples, Transactions of the Japan Society of Mechanical Engineers, Vol.80, No.820 (2014), pp.1-12 (in Japanese).

NEDO (New Energy and Industry Technology Development Organization) Department of Fuel Cell and Hydrogen Technology, Road Map 2010 of NEDO Fuel Cell and Hydrogen Technology Development, available from <http://www.nedo.go.jp/content/100642949.pdf>, (accessed on 16 April, 2016) (in Japanese).

Nishimura, A., Shibuya, K., Morimoto, A., Tanaka, S., Hirota, M., Nakamura, Y., Kojima, M., Narita, M. and E. Hu, Dominant factor and mechanism of coupling phenomena in single cell of polymer electrolyte fuel cell, Applied Energy, Vol.90 (2012), pp.73-79.

Nishimura, A., Shibuya, K., Morimoto, A., Tanaka, S., Hirota, M., Nakamura, Y., Kojima, M. and Narita, M., In-situ measurement of in-plane temperature distribution in a single-cell polymer electrolyte fuel cell using thermograph (1st report: impacts of gas flow rate at inlet and gas channel pitch of separator on in-plane temperature distribution and power generation performance), Journal of Environment and Engineering, Vol.6, No.1 (2011a), pp.1-16.

Nishimura, A., Tanaka, S., Kondo, H. and Hirota, M., Effect assessment of surface treatment and gas channel pitch of separator on in-plane temperature distribution and power generation performance of a single-cell polymer electrolyte fuel cell, Transactions of the Japan Society of Mechanical Engineers, Series B, Vol.77, No.784 (2011b), pp.2478-2491 (in Japanese).

Ogawa, T., Hohara, N., Chikahisa, T. Hishimura Y., Prospect of water production and temperature distribution in PEM fuel cells, Thermal Science and Engineering, Vol.23 (2004a), pp.93-94.

Ogawa, T., Hohara, N., Chikahisa, T. and Hishimura, Y. Observation of water production and temperature distribution in PEM fuel cells, Proceedings of the 41st National Heat Transfer Symposium of Japan (2004b), pp.235-236 (in Japanese).

Ogawa, T., Chikahisa and T. Kikuta, K., Measurement of fluctuating distribution in PEFC due to produced water, Proceedings of Thermal Engineering Conference (2003), pp.483-484 (in Japanese).

Quan, P., Zhou, B., Sobiesiak, A. and Liu, Z., Water behavior in serpentine micro-channel for proton exchange membrane fuel cell cathode, Journal of Power Sources, Vol.152 (2005), pp.131-145.

Quan, P. and Lai, M. C., Numerical study of water management in the air flow channel of a PEM fuel cell cathode, Journal of Power Sources, Vol.164 (2007), pp.222-237.

Springer, T. E., Zawodzinski, T. A. and Gottesfeld, S., Polymer electrolyte fuel cell model, Journal of Electrochemical Society, Vol.138, No.8 (1991), pp.2334-2341.

The Engineering ToolBox, available from <http://www.engineeringtoolbox.com/water-vapor-saturation-pressure-d_599.html>, (accessed on 14 April, 2016)

Tsuji, K., Domestic fuel cell co-generation system entering real commercial stage, Hydrogen Energy System, Vol.33 (2008), pp.93-96.

Wang, M., Guo, H. and Ma, C., Temperature distribution on the MEA surface of a PEMFC with serpentine channel flow bed, Journal of Power Sources, Vol.157 (2006), pp.181-187.

Zhang, G., Guo, L., Ma, L. and Liu, H., Simultaneous measurement of current and temperature distributions in a proton exchange membrane fuel cell, Journal of Power Sources, Vol.195 (2010), pp.3597-3604.

Zhang, G. and Kandlikar, S. G., A critical review of cooling techniques in proton exchange membrane fuel cell stacks, International Journal of Hydrogen Energy, Vol.37 (2012), pp.2412-2429.

Zhang, G., Shen, S., Guo, L. and Liu, H., Dynamic characteristics of local current densities and temperatures in proton exchange membrane fuel cells during reactant starvations, International Journal of Hydrogen Energy, Vol.37 (2012), pp.1884-1892.

Zhang, J., Kramer, D., Shimoi, R., Ono, Y., Lehmann, E., Wokaun, A., Shinohara, K., Scherer, G. G., In situ diagnostic of two-phase flow phenomena in polymer electrolyte fuel cells by neutron imaging, Part B. Material variations, Electrochimica Acta, Vol.51 (2006), pp.2715-2727.

Zhang, J., Xie Z., Zhang, J., Tang Y., Song, C., Nevessin, T., Shi, Z., Song, D., Wang, H., Wilikinson, D. P., Liu, Z. S. 
Nishimura, Yoshimura, Mahadi, Hirota and Kolhe, Mechanical Engineering Journal, Vol.3, No.5 (2016)

and Holdcroft, S., High temperature PEM fuel cells, Journal of Power Sources, Vol.160 (2006), pp.872-891. 